\title{
PEMANFAATAN METODE LOCATION BASED SERVICE DALAM PEMETAAN FASILITAS KESEHATAN DI KOTA PADANG
}

\author{
Yance Sonatha $^{1}$, Meri Azmi ${ }^{2}, \operatorname{Rasyidah}^{3}$, Tri Lestari ${ }^{4}$, Taufik Gusman ${ }^{5}$ \\ Jurusan Teknologi Informasi Politeknik Negeri Padang 1,2,3,4,5 \\ Jalan Kampus, Limau Manis, Kec. Pauh, Kota Padang, 25164 \\ Sur-el : sonatha.yance@gmail.com ${ }^{1}$, meriazmi@gmail.com ${ }^{2}$
}

\begin{abstract}
The need for health services is one of the important factors at this time. People want to quickly find the location of the nearest health service as they wish. But this will be a little difficult, if they are in an unfamiliar location. This research develops an application that can find the location of health facilities and is implemented in the city of Padang. The needs of user smartphone user in Padang City-are mapped by using requirement specification method that maps application requirements from both functional and non funstional sides. The design of this application uses Unified Modeling Language. This application was developed with the waterfall model and was built using the Location Based Services facilities provided by android. This application is built from two sides namely the android client and web server. The results of the research are an application that can find the location of the health facility in the city of Padang. The application can be accessed using an internet browser (server) and an android smartphone (client) with the minimum Android 5.0 operating system.
\end{abstract}

Keywords: Android, Health Facility, Location Based Services, Padang City, Unified Modelling Language (UML)

\begin{abstract}
Abstrak: Kebutuhan akan layanan kesehatan adalah salah satu faktor penting saat ini. Orang ingin dengan cepat menemukan lokasi layanan kesehatan terdekat sesuai keinginan mereka. Tetapi ini akan sedikit sulit, jika mereka berada di lokasi yang tidak dikenal. Penelitian ini mengembangkan aplikasi yang dapat menemukan lokasi fasilitas kesehatan dan diimplementasikan di kota Padang. Kebutuhan pengguna (pemakai smartphone di Kota Padang),dipetakan menggunakan metode tabel spesifikasi kebutuhan sistem yang memetakan kebutuhan aplikasi dari sisi fungsional dan non fungsional. Desain aplikasi ini menggunakan Unified Modeling Language. Aplikasi ini dikembangkan dengan model waterfall dan dibangun menggunakan metode Location Based Service yang disediakan oleh android. Aplikasi ini dibangun dari dua sisi yaitu client android dan server web. Penelitian ini menghasilkan sebuah aplikasi yang dapat menemukan lokasi fasilitas kesehatan yang diinginkan di Kota Padang. Aplikasi yang dapat diakses menggunakan browser internet (server) dan smartphone android (client) dengan sistem operasi Android 5.0 minimum.
\end{abstract}

Kata kunci: Android, Fasilitas Kesehatan, Kota Padang, Location Based Services, Unified Modelling Language (UML)

\section{PENDAHULUAN}

Kesehatan adalah salah satu prioritas utama bagi hampir seluruh masyarakat di negara ini. Setiap orang tidak ingin sakit, dan ketika itu terjadi, mereka ingin segera mengatasinya. Mengunjungi fasilitas kesehatan seperti pusat kesehatan masyarakat, rumah sakit dan klinik dokter adalah upaya untuk memulihkan kondisi kesehatan. Pengetahuan tentang lokasi dan fasilitas yang ditawarkan dari fasilitas kesehatan terdekat adalah satu hal yang dibutuhkan.

Berdasarkan data dari Departemen Kesehatan Kota Padang pada tahun 2018, ada 26 unit rumah sakit di Kota Padang (baik swasta maupun negeri) dan 23 unit pusat kesehatan 
masyarakat. Jumlah klinik dokter di Kota Padang tercatat sejumlah 97 unit. [1]

Sementara itu, perkembangan teknologi saat ini terutama smartphone sangat pesat. Gambar 1 menunjukkan bahwa jumlah pengguna smartphone di Indonesia telah meningkat dari hanya 11,7 juta pada 2011 menjadi 76,64 juta pada 2019. Jumlah ini diprediksi mencapai 89,86 juta pada 2022. [2]

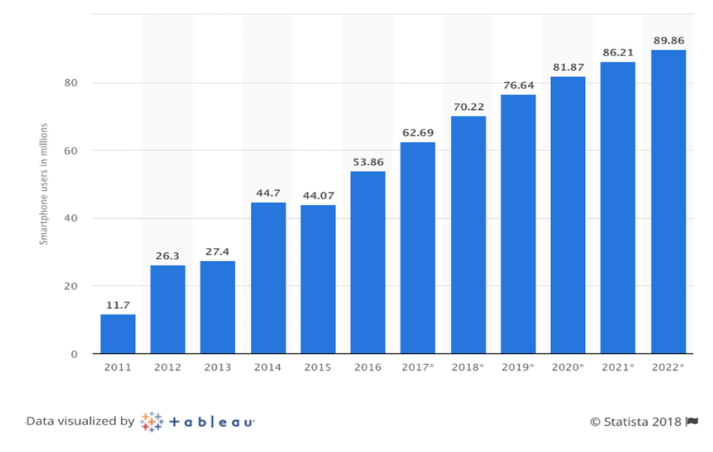

Gambar 1. The number of smartphone users in Indonesia [3]

(Sumber : https:// www.statista.com/statistics/266729/ $\underline{\text { smartphone-users-in-indonesia/ ) }}$

Saat ini, banyak orang menggunakan teknologi untuk menemukan lokasi tertentu, termasuk menggunakan layanan berbasis lokasi yang tersedia di perangkat smartphone. Banyak studi penelitian terkait tentang pengembangan aplikasi pencarian lokasi (location based services), termasuk mencari lokasi penyebaran hutan lindung di Lampung [4], memetakan lokasi, dan menyajikan rute terdekat ke fasilitas kesehatan kota [5], menjadikan web sebagai pemetaan masjid di Samarinda [6] dan penelitian tentang pemetaan lokasi pendidikan tinggi menggunakan ArcView. [7]

Penelitian ini bertujuan untuk mengembangkan aplikasi yang tidak hanya menyediakan informasi tentang lokasi fasilitas kesehatan di kota Padang, tetapi juga memberikan informasi tentang layanan yang ditawarkan oleh masing-masing fasilitas kesehatan, jarak terdekat dari pengguna dan informasi kesehatan lainnya. Fasilitas kesehatan dalam penelitian ini meliputi rumah sakit, pusat kesehatan masyarakat, klinik dokter, apotek, dan klinik kecantikan.

Sistem Informasi Geografis (SIG) adalah sistem yang digunakan untuk menyimpan dan memanipulasi informasi-informasi geografi dan berbasis komputer. SIG dirancang untuk mengumpulkan, menyimpan, dan menganalisis objek-objek dan fenomena dimana lokasi geografi merupakan karakteristik yang penting atau kritis untuk dianalisis [8]

Android adalah sistem operasi untuk perangkat seluler berbasis linux dan memiliki platform open source untuk membangun dan mengembangkan aplikasi. Aplikasi Android dikembangkan dengan menggunakan bahasa pemrograman Java. [9]

Android SDK merupakan tools API (Application Programming Interface) untuk pengembangan aplikasi pada platform android menggunakan bahasa Java. Sekarang ini Android $S D K$ digunakan untuk alat bantu dan $A P I$ untuk mengembangkan aplikasi. Android adalah subset perangkat lunak untuk ponsel yang meliputi sistem operasi, middleware dan aplikasi kunci yang dirilis oleh Google.[9]

Android SDK ini membantu proses pengembangan aplikasi yang berisi berbagai tools dan library. Saat menggunakan Android Studio sebagai lingkungan pengembangan 
aplikasi Android, SDK ini telah disertakan dalam instalasi Android Studio.[10]

Global Positioning System atau GPS adalah sistem atau perangkat yang dapat memberikan informasi tentang posisi pengguna. GPS bekerja berdasarkan satelit dan dapat diakses global, tidak terbatas pada ruang lingkup tertentu. Data dikirim dari satelit dalam bentuk data digital yang memanfaatkan gelombang radio. Satelit yang memanfaatkan GPS pertama kali digunakan oleh Departemen Pertahanan Amerika Serikat pada tahun 1978 dan pada tahun 1994 sudah terdapat 24 satelit (21 satelit aktif dan 3 cadangan).

Layanan GPS pada awalnya hanya digunakan untuk keperluan militer, tetapi sejak 1980 layanan ini dapat digunakan oleh publik. Layanan GPS itu sendiri dapat digunakan oleh semua orang secara gratis. Satelit itu digunakan untuk mengorbit pada ketinggian sekitar 12.000 mil dari permukaan bumi. Ini dianggap posisi yang paling ideal karena satelit dapat menjangkau area yang lebih luas. Maka semua satelit yang bekerja akan selalu berada dalam posisi yang dapat menutupi semua area di permukaan bumi. Ini bertujuan untuk meminimalkan keberadaan titik-titik kosong (area yang tidak tercakup oleh satelit). [11]

\section{METODOLOGI PENELITIAN}

Metodologi yang digunakan dalam penelitian ini mengadaptasi model waterfall. Model waterfall, kadang-kadang disebut classic life cycle, merujuk pada pendekatan sistematis dan berurutan untuk pengembangan perangkat lunak yang dimulai dengan spesifikasi kebutuhan pelanggan dan berkembang melalui perencanaan, pemodelan, konstruksi, dan penyebaran, yang menitikberatkan pada dukungan berkelanjutan dari penyelesaian perangkat lunak. [12]

Tahapan yang dilewati dalam penyelesaian penelitian ini dapat dilihat pada gambar 2.

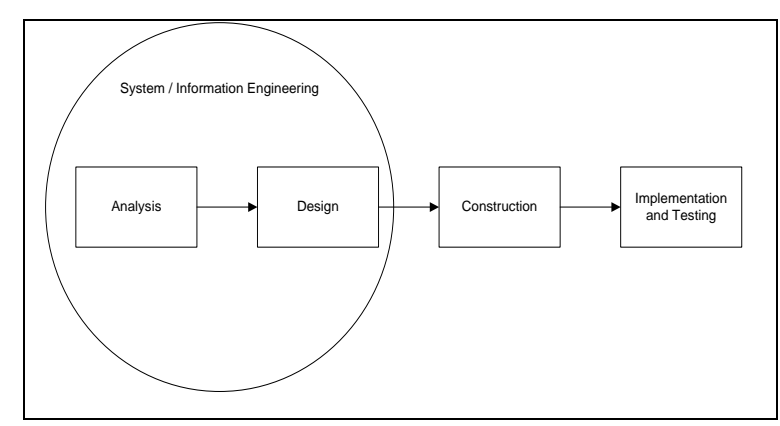

Gambar 2. Model Waterfall

1) Tahap analisis. Pada tahap ini dilakukan analisis kebutuhan sistem. Hasil dari tahap ini adalah pemetaan kebutuhan dalam bentuk tabel spesifikasi kebutuhan sistem.

2) Tahap desain. Fokus pada tahap ini adalah untuk menentukan, menggambarkan, membangun, dan mendokumentasikan pengembangan perangkat lunak. Dalam penelitian ini, digunakan Unified Modeling Language (UML) digunakan sebagai alat bantu desain.

3) Tahap konstruksi. Hasil desain dari tahap sebelumnya dikonversi menjadi kode pemrograman.

4) Tahap implementasi dan pengujian. Aplikasi siap pakai diuji dengan menggunakan data nyata, dan diimplementasikan dari kedua sisi (client dan server). 


\section{HASIL DAN PEMBAHASAN}

Dari hasil analisis kebutuhan diperoleh spesifikasi sistem dalam menemukan fasilitas kesehatan terdekat di Kota Padang. Tabel 1 berikut menunjukkan spesifikasi kebutuhan sistem yang terdiri dari fungsional dan non fungsional yang diharapkan pengguna ada di sistem yang akan dikembangkan.

\section{Tabel 1. Spesifikasi Kebutuhan Sistem}

\begin{tabular}{ll}
\hline SRS- & \multicolumn{1}{c}{ Keterangan } \\
ID & \\
\hline F-01 & $\begin{array}{l}\text { Masyarakat sebagai pengguna dapat } \\
\text { menginstal aplikasi pada smartphone }\end{array}$ \\
F-02 & $\begin{array}{l}\text { Pengguna dapat menjalankan aplikasi pada } \\
\text { smartphone }\end{array}$ \\
F-03 & $\begin{array}{l}\text { Pengguna dapat melihat informasi lokasi } \\
\text { fasilitas umum bidang kesehatan }\end{array}$ \\
& $\begin{array}{l}\text { Pengguna dapat melihat petunjuk arah } \\
\text { menuju lokasi fasilitas umum bidang } \\
\text { kesehatan yang dituju }\end{array}$ \\
F-05 & $\begin{array}{l}\text { Pengguna dapat melakukan pencarian } \\
\text { lokasi fasilitas umum bidang kesehatan }\end{array}$ \\
& $\begin{array}{l}\text { yang diinginkan } \\
\text { Aplikasi } u s e r \text { friendly bagi pengguna } \\
\text { NF-01 }\end{array}$ \\
NF-02 & $\begin{array}{l}\text { Menpilan aplikasi menarik. } \\
\text { selalu update }\end{array}$ \\
\hline
\end{tabular}

Aplikasi ini dibangun dari dua sisi: client dan server. Client adalah komunitas pengguna aplikasi yang memiliki smartphone dengan aplikasi yang sudah ada didalamnya. Dan server adalah sistem yang menyediakan dan mengelola informasi entang fasilitas kesehatan masyarakat di kota Padang, penggunanya dinamakan dengan admin sistem. Desain sistem umum pada sisi server dapat dilihat pada gambar 3 dan pada sisi client dapat dilihat pada gambar 4 .

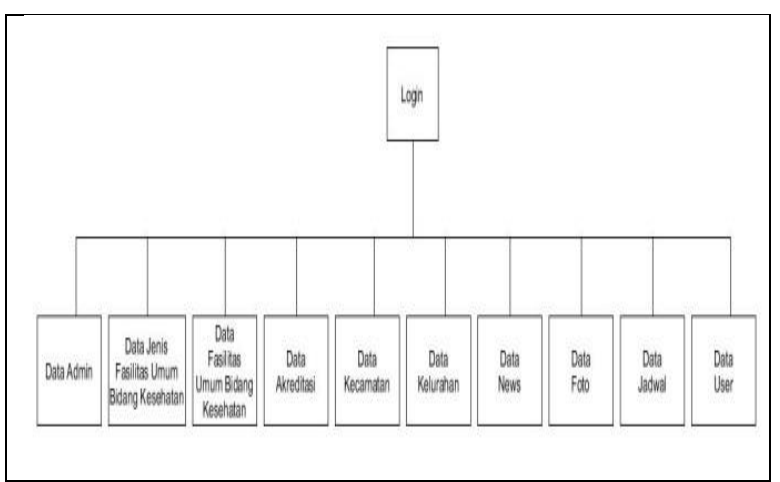

Gambar 3. Desain Aplikasi Server

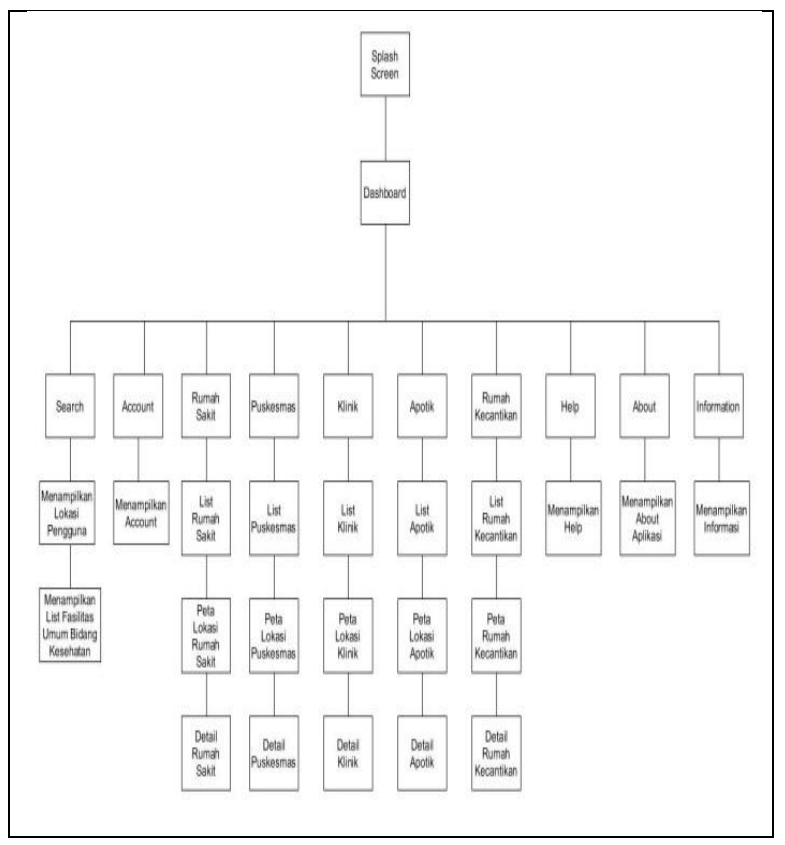

Gambar 4. Desain Aplikasi Client

Use case diagram digunakan untuk menggambarkan urutan interaksi aktor pada sistem. Use case yang akan dirancang yaitu untuk aktor user sebagai pengguna dan aktor admin sebagai pengelola data aplikasi [13]. Use case diagram admin sebagai aktor aplikasi dapat dilihat pada Gambar 5. 


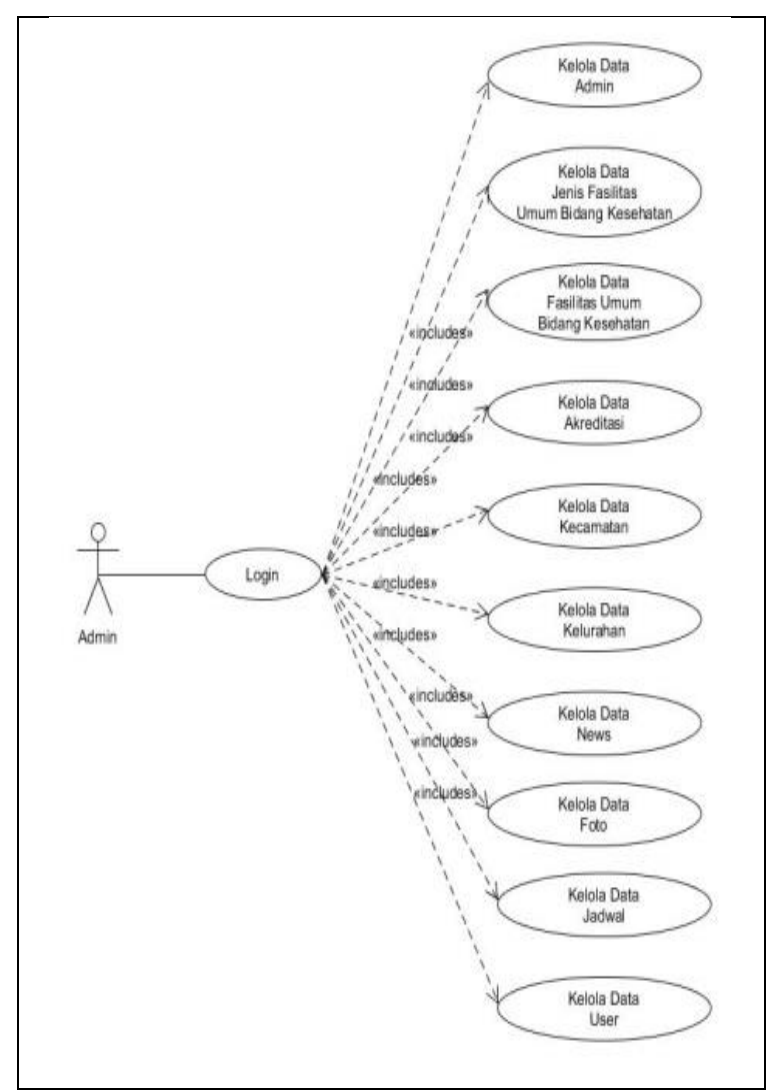

Gambar 5. Use Case Diagram Aktor Admin

Sedangkan use case diagram untuk aktor user dapat dilihat pada Gambar 6 berikut.

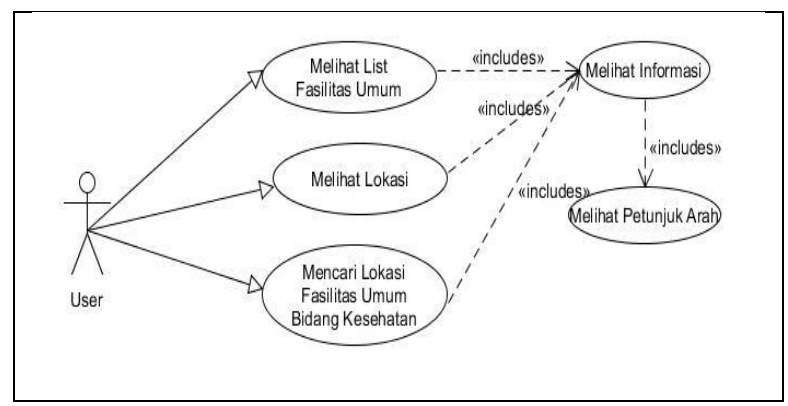

Gambar 6. Use Case Diagram Aktor User

Class diagram menggambarkan deskripsi dan struktur objek dan class yang terhubung [13]. Class diagram aplikasi dapat dilihat pada gambar 7 berikut.

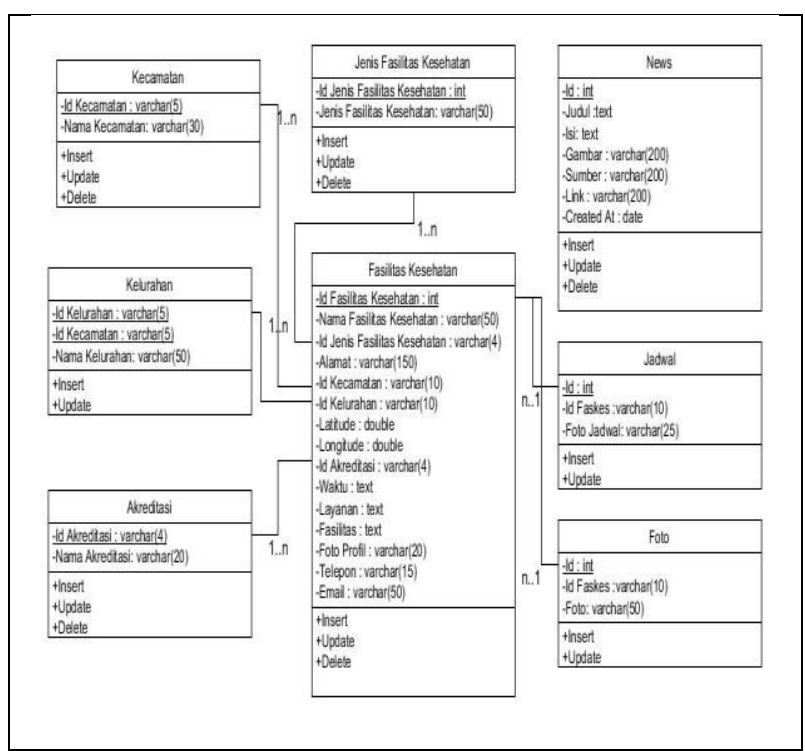

\section{Gambar 7. Class Diagram}

Pengembangan sistem didasarkan pada desain yang ada sebelumnya, dengan spesifikasi perangkat lunak yang dibutuhkan :

1) Perangkat lunak untuk pengembangan server: netbeans 8.2 , xampp server

2) Perangkat lunak untuk pengembangan client: Android SDK, Android Studio

3) Perangkat lunak untuk implementasi sistem: smartphone android 5.0 minimum

Tahapan ini dilakukan dengan mengujikan aplikasi dari kedua sisi yakni client dan server. Tampilan pertama setelah aplikasi dijalankan adalah splashscreen yang berjalan selama 3 detik, kemudian menu utama muncul seperti yang ditunjukkan pada Gambar 8. 


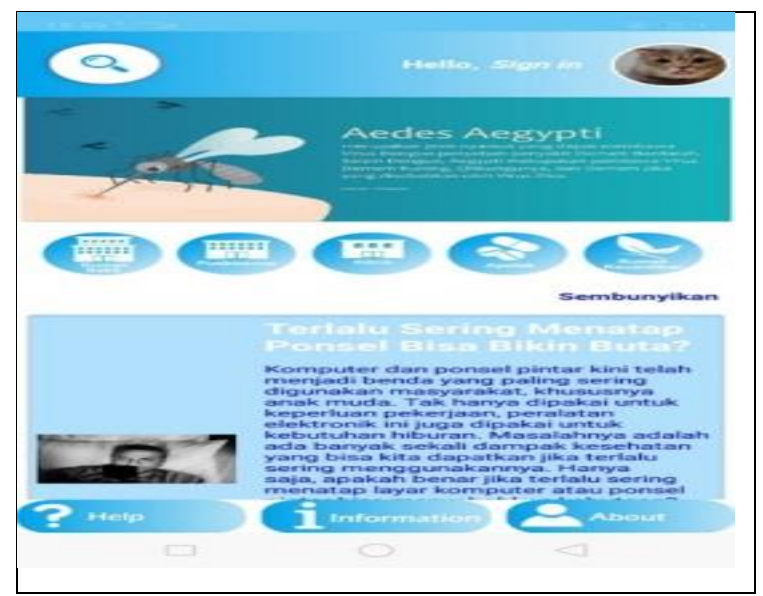

Gambar 8. Menu Utama Client Android

Gambar 9 menunjukkan daftar rumah sakit di Padang. Setiap rumah sakit dilengkapi dengan informasi detail tentang layanannya seperti yang terlihat pada Gambar 10.

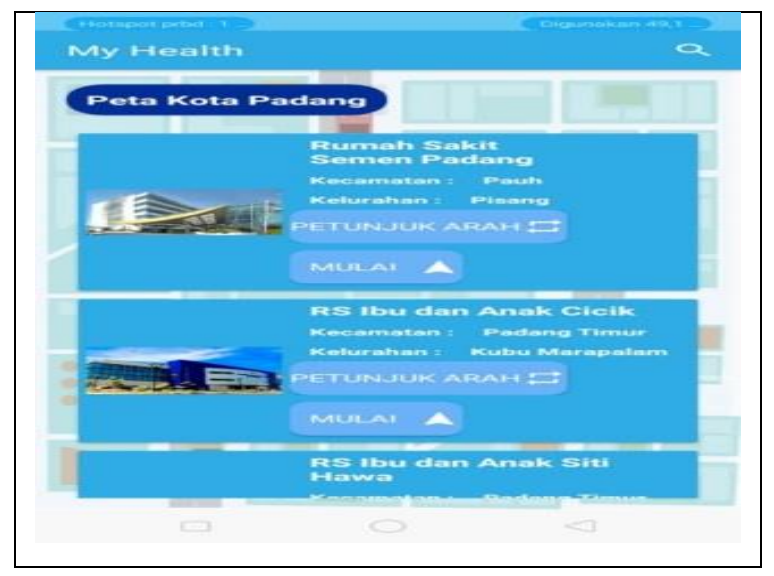

Gambar 9. Daftar Rumah Sakit di Kota Padang

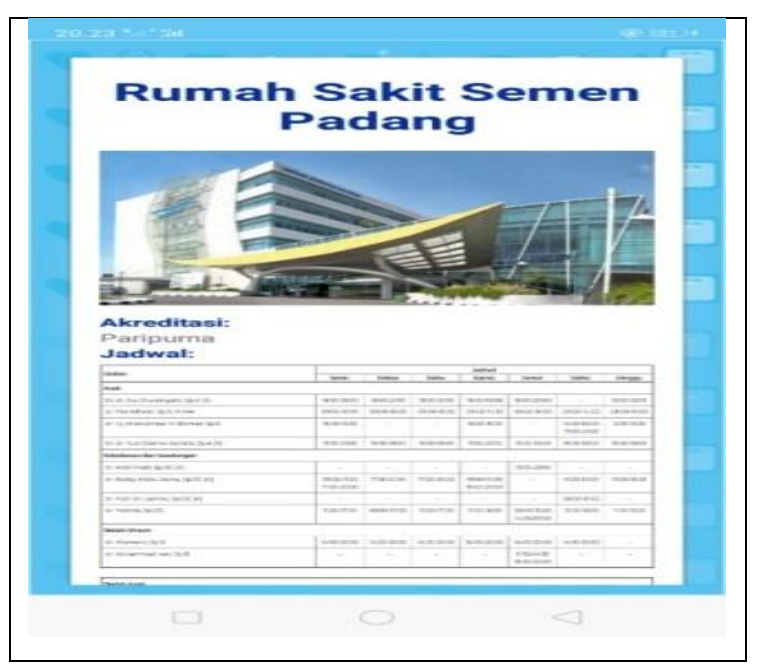

Gambar 10. Rincian Data Rumah Sakit
Dalam menu rincian rumah sakit dapat diperoleh informasi mengenai status akreditasi rumah sakit, fasilitas dan layanan yang ditawarkan serta jadwal praktik dokter yang ada. Aplikasi juga menampilkan peta lokasi rumah sakit seperti terlihat pada Gambar 1.

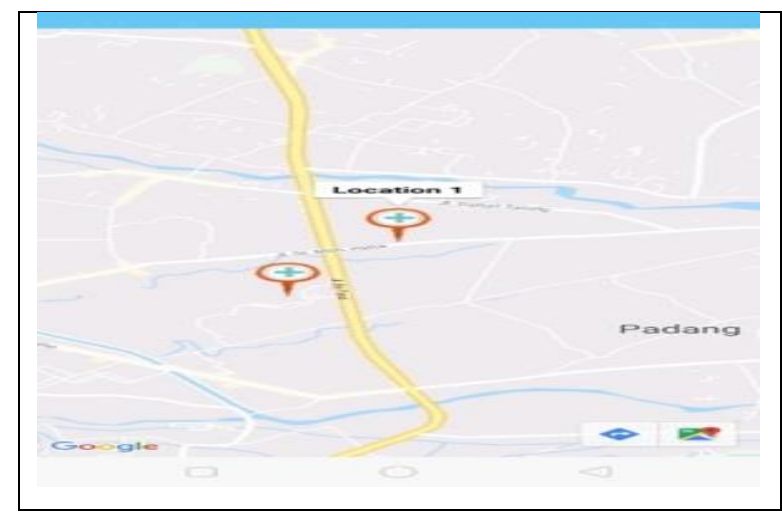

Gambar 11. Peta Lokasi Rumah Sakit

Jika button penunjuk arah dipilih, maka aplikasi langsung terkoneksi dengan fasilitas google maps seperti terlihat pada Gambar 12.

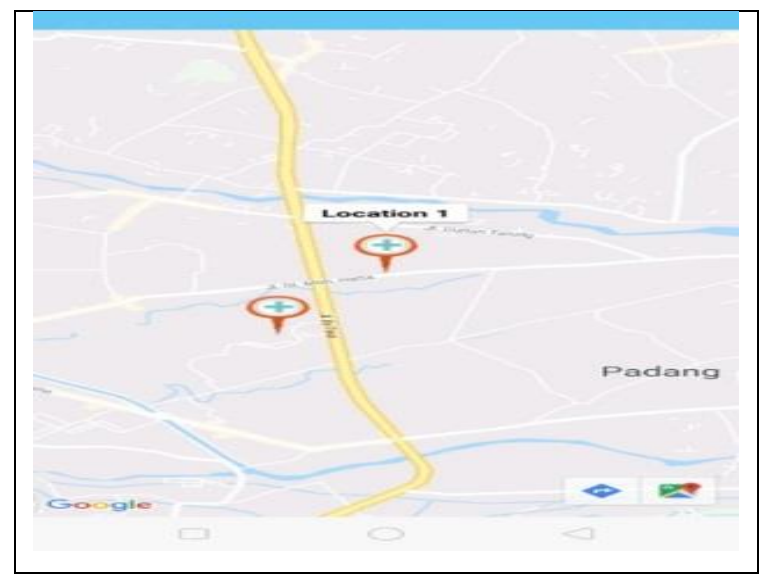

Gambar 12. Tampilan Button Penunjuk

Arah

Proses yang sama juga dapat dilakukan untuk menu fasilitas kesehatan lainnya, yakni puskesmas, klinik, apotik maupun rumah kecantikan. Untuk masuk ke halaman awal server, admin harus melakukan login terlebih dahulu,seperti terlihat pada Gambar 13. 


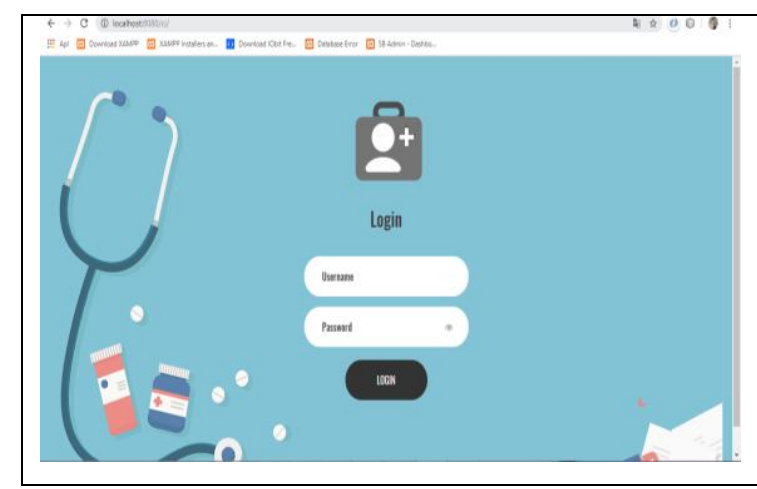

Gambar 13. Menu login

Jika admin berhasil login, maka akan tampil halaman utama seperti terlihat pada Gambar 14.

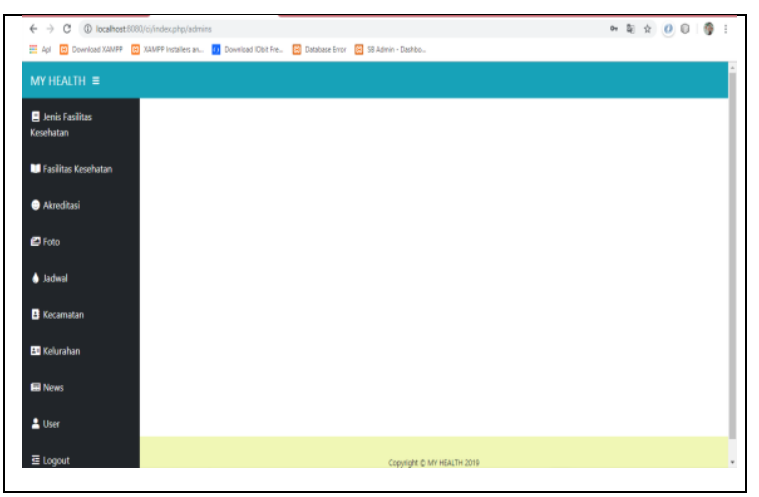

Gambar 14. Halaman Awal Server

Pada halaman utama server tersebut dapat dilihat beragam menu yang bisa diakses oleh admin sistem, diantaranya menu jenis dan rincian fasilitas kesehatan, akreditasi, foto, jadwal, kecamatan, kelurahan, berita dan user. Admin memiliki wewenang dalam melakukan penambahan, perubahan dan penghapusan terhadap isi menu sesuai dengan hasil desain sebelumnya.

Beberapa tampilan menu yang bisa diakses oleh admin sistem, diantaranya menu akreditasi seperti pada Gambar 15.

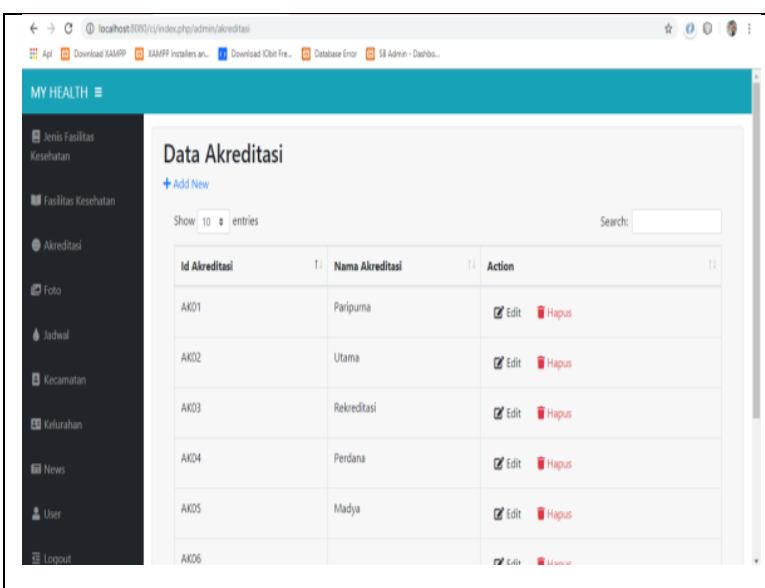

Gambar 15. Menu Pengaturan Akreditasi Rumah Sakit

\section{KESIMPULAN}

Penelitian ini telah berhasil membangun aplikasi yang dapat memberikan kemudahan bagi pengguna untuk dapat menemukan beberapa titik lokasi fasilitas kesehatan yang mereka inginkan. Aplikasi ini dilengkapi dengan informasi kesehatan dan menampilkan titik lokasi pengguna dengan lokasi tujuan. Aplikasi ini berjalan dengan baik di smartphone dengan operasi sistem minimum Android 5.0. Aplikasi ini perlu dikembangkan lebih lanjut sehingga bisa menjadi aplikasi prototipe yang bisa digunakan di mana saja.

\section{DAFTAR PUSTAKA}

[1] Dinas Kesehatan Kota Padang : Profil Dinas Kesehatan Kota Padang, padang. 2018

[2] Machmud, K., "The Smartphone Use in Indonesian School : The High Students' Perspectives"., Journal of Arts \& Humanities Volume 7 Issues 03. 2018

[3] https://www.statista.com/statistics/321485/ smartphone-user-penetration-in-indonesia/ date access: October $20^{\text {th }} .2019$ 
[4] Amnah, "Rancang Bangun Sistem Informasi Geografis Penyebaran Hutan Lindung Pada Provinsi Lampung", Jurnal Tim Darmajaya, 2(1),pp. 63-78.2016

[5] Naibaho, Jimmy Febrinus, "Pemetaan Informasi Sarana Kesehatan Masyarakat Serta Penyajian Rute Terdekat Menuju Lokasi Sarana Pelayanan Kesehatan Pada Wilayah Kota Berbasis Online", Prosiding Seminar Nasional Pendidikan Teknik Informatika, pp. 181-187. 2016

[6] Maharani, Septya., Dina Apriani., Awang Harsa Kridalaksana, "Sistem Informasi Geografis Pemetaan Masjid Di Samarinda Berbasis Web", Jurnal Informatika, 11(1), pp. 9-20. 2017

[7] Supuwiningsih, Ni Nyoman., dkk, "Sistem Informasi Geografis Pemetaan Pendidikan Tinggi Di Pulau Bali Menggunakan Arcview", International Journal of Engineering Technologies and Management Research, 5(5), 167-178. 2018

[8] Mierzejowska, A., Zogala,M., "The Characteristics of Geographical Information Systems in term of Their Current Use", Journal of Water and Land Development, No.39 (X-XII),pp 101-108. 2018

[9] Safaat, Nazruddin H. Android Pemrograman Apliaksi Mobile Smartpjone dan Tablet PC Berbasis Android. Bandung: Informatika Bandung. 2014

[10] Hansun, Seng., Kristanda, Marcel Bonar., Saputra, Michael Wijaya. Pemrograman Android dengan Android Studio IDE. Yogyakarta: ANDI . 2018

[11] Faiqunisa., Pratama, G. A. "Monitoring Aktivitas Keluarga Berbasis GPS Tracking”. Jurnal Teknologi Informasi dan Komunikasi, 5(1), 2-3. 2016

[12] Pressman, R., "Software Engineering $A$ Practitioner's Approach Seventh Edition", Mc Graw Hill 2010

[13] S, Rosa A., dan Muhammad Shalahuddin, "Rekayasa Perangkat Lunak Terstruktur dan Berorientasi Objek" Bandung: Informatika. 2018 